\title{
Integration of Climate Change into the Senior Secondary School Agricultural Science Curriculum in Nigeria
}

\author{
Michael E. Ikehi, Florence O. Ifeanyieze, Cajethan U. Ugwuoke \\ Department of Vocational Teacher Education, University of Nigeria, Nsukka, Nigeria \\ Email: ikehidon1@yahoo.com, floraoby2001@yahoo.com, cajuche2@yahoo.com
}

Received 3 June 2014; revised 5 July 2014; accepted 2 August 2014

Copyright (C) 2014 by authors and Scientific Research Publishing Inc.

This work is licensed under the Creative Commons Attribution International License (CC BY). http://creativecommons.org/licenses/by/4.0/

(c) (i) Open Access

\section{Abstract}

The study was carried out to identify content areas of climate change for integration into the senior secondary school agricultural science curriculum in countries such as Nigeria. Two research questions were developed and answered by the study while two null hypotheses were formulated and tested. Descriptive survey research design was adopted for the study. The population for the study was 441 while the sample was 249 . A 34-item structured questionnaire was developed for data collection. The questionnaire items were face-validated by five experts while Cronbach alpha method was used to determine the internal consistency of the items. The copies of the questionnaire were administered to the respondents with the help of two research assistants. Weighted mean was used to answer the research questions while t-test statistic was used to test the null hypotheses at 0.05 level of significance and 240 degrees of freedom. The findings of the study revealed that four clusters with 23 items were required for integration in the curriculum while 11 materials were identified to help teach the content areas. It was also found that there was no significant ( $p>0.05)$ difference in the mean responses of Lecturers and extension agents on each item in the content areas of climate change and materials for teaching them. The study recommended among others that the clusters and 23 items with the materials identified by the study should be integrated into the agricultural science curriculum for teaching in secondary schools, especially in Nigeria.

\section{Keywords}

Climate Change, Curriculum, Secondary School, Agricultural Science, Integration

\section{Introduction}

Change in any environment causes shift in the entire ecosystem. Climate is a fundamental element of the envi-

How to cite this paper: Ikehi, M.E., Ifeanyieze, F.O. and Ugwuoke, C.U. (2014) Integration of Climate Change into the Senior Secondary School Agricultural Science Curriculum in Nigeria. Atmospheric and Climate Sciences, 4, 614-621. 
ronment that causes alteration in an ecosystem if its variation becomes erratic. The shift resulting from climate change affects elements of an entire environment which makes climate change a global issue but at various levels of impact.

Climate change is a variation of the average weather attributed directly or indirectly to human activities in addition to natural events that alter the composition of the atmosphere. [1] defined climate change as significant variations in the statistical properties of the average weather condition when considered over long periods of time regardless of the cause. Climate change is mainly caused by increase in the greenhouse gasses, human activities like deforestation, clean clearing, and use of factory machines, generators and cars among others. In the view of [2], increased greenhouse gas is the major cause of climate change while [3] further attributed climate change to deforestation and other practices and activities for agricultural and industrial purposes. [4] indicated that since industrial revolution, human activities have contributed to increase in concentration of atmospheric greenhouse gases such as carbon IV oxide by one third. Climate change has acclaimed to have varying effects and has been known to affect people at home, offices and schools [5]. [5] further explained that climate change has resulted in increased heat in the classrooms causing discomfort and impeding learning in addition to flooding of school compounds, roads as well as destroying school buildings consequently leading to irregular attendance to schools (during rainy seasons) especially in rural areas while in extreme cases forcing closedown of schools for the periods. Climate change resulted to heavy rainfall in some part of Nigeria in 2012 and displaced farming families from their farm lands and residential places. It is obvious that climate change is impacting negatively on life thus it is necessary to create awareness about climate variations and its attributes to learners in secondary schools.

Secondary schools are educational institutions below tertiary level established to inculcate in learners the societal needs, values and challenges which are dynamic in nature. This implies that societal needs and challenges are channeled to the formal educational institutions as ways of preparing members to properly deal with such issues and challenges as they arise. The societal needs and challenges are usually reflected in schools curriculum.

Curriculum is the subject contents which learners and teachers must cover in order to achieve set goals and objectives [6]. It refers to series of activities intended to be completed in order to acquire desirable knowledge, skills, attitudes, and values of the society. Some authors conceived curriculum as the document used as instructional guide in formal institutions [7]. In the view of [8], curriculum is a deliberately and systematically planned attempt to change the behavior of young and inexperienced to enable them gain the insight that helps them solve problems for a better society. The author further explained curriculum as an instrument through which schools seek to translate the hopes of the society into concrete reality. Curriculum is therefore a deliberately and systematically planned body of knowledge, skills and attitudes grouped into subject topics taught to learners in schools. However, whether at the primary and/or secondary school level, what is generally regarded as the curriculum is the list of subject topics taught in the school which varies with level depending on societal needs [8]. Examples of such subjects include English, Mathematics, chemistry, Biology and Agricultural science among others.

Agricultural science is the application of scientific principles in rearing animals and producing crops for food, fiber, bio-fuel, drugs and other products used in sustaining and enhancing human life [9]. Agricultural science is defined as the application of scientific principles for successful production of crops and livestock for man's benefit [10]. Agricultural science, as a subject in secondary schools in Nigeria, seeks to teach the students the principles of using scarce resources to produce crops and animals to feed the world's population while preventing problems that may affect human health, environment and the society in general. Agricultural activities depend highly on climate thus a change in its statistical distribution has a direct impact on production and performance of crops and animals thus making the industry the most vulnerable to weather variations. It is well established that climate change poses a serious threat to agricultural production, particularly on rain-fed agriculture. For instance, climate change results in stunted growth and low yield of food crops, late fruiting of tree crops, easy spread of pests and diseases on crops and livestock. Thus it impinges directly on food security. [11] opined that a well-informed citizenry, responsive institutions, and problem-focused knowledge generation are key elements for effectively addressing challenges emerging from climate change. It therefore implies that climate change and its variables like causes, effects, mitigation could be integrated into the secondary school agricultural science curriculum to equip learners with the necessary skills for adaptation.

Integration is the incorporation of something into another with the view for improvement. Integration in this 
study means addition of climate change to the senior secondary school Agricultural Science Curriculum with the aim of inculcating in students the meaning, causes, effects, mitigation and adaptation strategies on climate change. It therefore means that if education is going to make a contribution to the current challenge on weather variations, integrating climate change into the curriculum becomes necessary to ensure that students at the senior secondary school level are abreast with the climate change issues including mitigation and adaptation strategies as a tool for combating the impacts. It is observed that children of developing countries are the most vulnerable with little awareness and coping capacity [3]. Therefore, to respond to the needs of children most at-risk and marginalized by climate change, quality education must be the channel to make all girls and boys more resilient to the impacts of climate change [12]. In the view of [13] children develop environmental interest, ecological understanding of empathy/moral and social understanding between ages 8 to 14 years. This age range corresponds to the ages of students in most Nigerian secondary schools, thus a need for improved curriculum/syllabus to include climate change. [14] stated that today's youths are most likely to experience and suffer the effects of climate change in future and they will be forced to address the issue or vanish with the vanishing resources. According to [14], much efforts and researches are being put for adaptation and mitigation strategies with less in preparing the most affected group (the young people) who will determine the future of the planet based on how prepared they are today. The curriculum content and teaching materials could be designed in such a way as to equip the students with the necessary knowledge, skills and attitudes to tackle this global issue. Curriculum for secondary schools in most African region and Nigeria in particular do not have contextualized information on climate change and thus it is advised that academic institutions with programmes in agricultural science are in a perfect position to foster the next generation of leaders and professionals needed to address these challenges [5], as it has become crucial for teachers of agricultural science to educate themselves and their students with complete and accurate information on climate change. One of the step necessary to achieve this is the integration of climate change and its related matters in the curriculum especially at the senior secondary school level to create early awareness and expose students to effects, causes, and mitigation or adaptation strategies to enhance their capacity as well as prepare them for the future climate related challenges in the society. [5] believe that educating children currently at school about climate change will help to shape and sustain future policymakers and will provide the rural sector with informed youths well prepared to deal with issues of climate change in their locality.

Integrating climate change into the senior secondary school agricultural science curriculum requires some approaches. The first consideration for modification of a curriculum is the situational analysis to determine a need for the integration of a body of knowledge into the exiting curriculum, the content to integrate, the materials among others [8]. With reference to the situational analysis [15] observed that climate issues are treated in the social science subject in most secondary schools, and usually with limited information and correlation to agricultural production. Few topics treated are usually elementary focusing on climate and its elements like rainfall, temperature and wind without due consideration to its extensive impact on food security, which is the order of the day, thus a need for full integration of not just climate but climate change and allied topics in agricultural science for professional handling. In modifying the curriculum of agricultural science in secondary schools, some authors [5] suggested the inclusion of areas such as introduction to climate change, global warming, agrobiodiversity, bio-fuels, adaptation strategies, mitigation strategies and global policy issues on climate change. The authors further suggested designed module to help teachers understand climate change issues in a global and regionally relevant context, and incorporate lessons into their curriculum, to include activities such as the 1) atmosphere and the earth's energy budget, 2) weather and climate, 3) climate change, 4) developing lesson plans. Recommended teaching methods include lecture (including guest lecture), seminars, group discussions, visits to sites, demonstrating the impact of climate change and or adaptation and mitigation strategies in use, on-farm discussions and survey in addition to E-Learning enhanced with research repositories where possible [7]. Curriculum content on climate change could be based on agro-bio-diversity, biofuels, mitigation strategies as well as global policy issues [16].

In considering the areas of climate change to be included in the curriculum, the researchers studied the senior secondary school agricultural science curriculum in Nigeria and discovered that the curriculum is divided into three: SSI, SSII and SSIII with specific themes and topics. Senior secondary I (SSI) curriculum has four themes, each of the four themes has 6, 8, 6 and 3 topics respectively. Theme 2 number 5 focused on "Environmental factors affecting agricultural productivity". Teachers are expected to: a) state the environmental factors that affect agricultural productivity such as climatic factors with bias in rainfall, temperature, wind and light among 
others and b) explain inter-relationship among living things. SSII has 7 themes with 4, 3, 2, 4, 3 , 7 and 7 topics respectively. Theme 6 topic number 4 focused on environmental physiology with emphasis on effects of climate on growth, reproduction, milk and egg production. SSIII has three themes with 1, 4 and 5 topics respectively with none focusing on any aspect of the climate change. The analysis of the curriculum revealed that SSI theme 2 topic number 5 and SSII theme 6 topic number 4 could have been the aspect of the curriculum to treat climate change and its variables but that was omitted. The researchers further interviewed teachers and the general public on the need to integrate climate change into the senior secondary school agricultural science curriculum. The interview revealed that it is necessary to integrate it into the curriculum but there are questions as to the area of climate change to integrate and the materials required for its delivery and evaluation; hence the study.

The major purpose of this study was to investigate the areas of climate change to be integrated into the curriculum of secondary school Agricultural Science in Nigeria. Specifically, the study sought to identify:

1) Themes and topics on climate change required to be integrated in the curriculum.

2) Materials required for effective teaching of the themes and topics on climate change.

\section{Methodology}

Two research questions were developed and answered by the study while two null hypotheses were formulated and tested at the probability of 0.05 level of significance. Descriptive survey research design was adopted for the study. The population for the study was 441, made up of 57 Lecturers of Agricultural Education in Universities and 384 extension agents in Nigeria (University Calendar 2013 and Ministry of Agriculture ADP Unit 2013). The sample for the study was 249 made up of 57 Lecturers $\left(\bar{x}_{\mathrm{L}}\right)$ and 192 extension agents $\left(\bar{X}_{\mathrm{E}}\right)$. The entire population of Lecturers was studied while stratified random sampling techniques was used to select $50 \%$ of the extension agents. A 34 item structured questionnaire was developed from the literature reviewed for the study and utilized in collecting data. Each item in the questionnaire was assigned a four response options of Highly Required (HR), Averagely Required (AR), Slightly Required (SR) and Not Required (NR) with values 4, 3, 2 and 1 respectively. The structured questionnaire items were face-validated by five experts; two lecturers from the Department of Technology and Vocational Education, Enugu State University of Science and Technology and three lecturers from Department of Geography University of Nigeria, Nsukka. Cronbach alpha method was used to determine the internal consistency of the questionnaire items and an average coefficient of 0.95 was obtained (0.96, 0.95, 0.87, 0.97 and 0.93). The questionnaire was administered on 249 respondents with the help of two assistants who were selected based on their familiarity with the study area. Prior to the assignment, the assistants were instructed on how to administer and retrieve the copies of the questionnaire. Out of 249 copies of questionnaire administered, 242 (55 lecturers and 187 extension agents) were retrieved, representing a return rate of $97 \%$. Therefore 242 copies of the questionnaire were analyzed. Weighted mean was used to answer the research questions; standard deviation was used to validate the mean while t-test statistic was used to test the null hypotheses at the probability of 0.05 level of significant and 240 degrees of freedom. In answering research questions each item was assigned real limit of numbers as follows $\mathrm{HR}=3.50-4.00$; $\mathrm{AR}=2.50-3.49$; $\mathrm{SR}=1.50-2.49$; $\mathrm{NR}=1.00-1.49$. It therefore means that any item with a weighted grand mean $\left(\bar{x}_{\mathrm{G}}\right)$ value of 1.50 or above was interpreted as required while any item with a grand mean $\left(\bar{x}_{\mathrm{G}}\right)$ value less than 1.50 was not required. The standard deviation $\left(\mathrm{SD}_{\mathrm{G}}\right)$ was used to determine the closeness or otherwise of the respondents from the mean and to each other. Any item with a standard deviation of 1.96 or below showed that the respondents were close to the mean and to one another in their responses but any item with a standard deviation above 1.96 indicated that the respondents were not close to the mean and to one another in their responses. The null hypothesis of no significant difference (NS) was accepted for any item whose t-calculated (t-cal) value was lower than the t-critical value of 1.96 at the probability of 0.05 and rejected if on the contrary.

\section{Results}

The results of the study were obtained from the research questions answered and the hypotheses tested and presented in Table 1 and Table 2.

\subsection{Research Question 1}

What are the content areas of climate change required for integration into the senior secondary school Agricultural Science Curriculum? 
Table 1. Mean rating of the respondents on the content areas of climate change required for integration into the Agricultural Science Curriculum of Secondary schools. N = 242 (55 Lecturers \& 187 Extension agents).

\begin{tabular}{|c|c|c|c|c|c|c|c|c|c|c|}
\hline $\mathrm{S} / \mathbf{N}$ & Item statement on the content & $\bar{x}_{\mathrm{L}}$ & $\mathbf{S D}_{\mathrm{L}}$ & $\bar{x}_{\mathrm{E}}$ & $\mathrm{SD}_{\mathrm{E}}$ & $\bar{x}_{\mathrm{G}}$ & $\mathrm{SD}_{\mathrm{G}}$ & t-cal & \multicolumn{2}{|c|}{ Remark } \\
\hline $\begin{array}{c}\text { A } \\
1\end{array}$ & $\begin{array}{l}\text { Concept of climate change } \\
\text { Concept of climate, }\end{array}$ & 3.51 & 0.29 & 3.56 & 0.37 & 3.54 & 0.33 & 0.41 & Required & NS \\
\hline 2 & Meaning and importance of climate change & 3.52 & 0.56 & 3.72 & 0.89 & 3.62 & 0.73 & 1.01 & , & , \\
\hline $\begin{array}{c}\mathrm{B} \\
1\end{array}$ & $\begin{array}{l}\text { Caused of climate change } \\
\text { Agricultural activities like clearing, tilling }\end{array}$ & 3.65 & 0.39 & 3.78 & 0.76 & 3.73 & 0.57 & 0.56 & ” & ”, \\
\hline 2 & Deforestation & 3.12 & 0.51 & 3.86 & 0.77 & 3.49 & 0.64 & 0.30 & , & , \\
\hline 3 & Bush burning & 3.45 & 0.66 & 3.45 & 071 & 3.45 & 0.69 & 0.43 & , & , \\
\hline 4 & Burning of fossil fuels like coal, oil & 2.63 & 0.02 & 3.65 & 0.83 & 3.64 & 0.43 & 1.04 & , & , \\
\hline 5 & Release of green house gasses & 2.99 & 0.11 & 3.01 & 0.09 & 3.50 & 0.10 & 0.45 & , & , \\
\hline 6 & Watering of desert/irrigation & 3.41 & 0.49 & 3.23 & 0.84 & 3.32 & 0.67 & 0.62 & , & , \\
\hline 7 & $\mathrm{CO}_{2}$ from industrial and steam engines & 3.73 & 0.81 & 3.75 & 0.63 & 3.74 & 0.72 & 1.10 & , & , \\
\hline 8 & Increased refuse/waste dumps & 3.87 & 0.19 & 3.91 & 0.43 & 3.94 & 0.31 & 0.95 & , & , \\
\hline 9 & Ocean current process & 3.10 & 0.56 & 3.21 & 0.55 & 3.11 & 0.56 & 0.13 & ”, & , \\
\hline 10 & Gas flaring & 3.65 & 0.94 & 3.81 & 0.75 & 3.73 & 0.85 & 0.34 & , & , \\
\hline $\begin{array}{l}\mathrm{C} \\
1\end{array}$ & $\begin{array}{c}\text { Effect of climate change on } \\
\text { Aquatic lives }\end{array}$ & 3.45 & 0.42 & 3.62 & 0.57 & 3.54 & 0.45 & 0.29 & , & , \\
\hline 2 & Crops & 3.19 & 0.61 & 3.40 & 0.68 & 3.29 & 0.65 & 0.40 & , & , \\
\hline 3 & Farming families & 3.18 & 0.14 & 3.10 & 0.16 & 3.14 & 0.10 & 0.19 & , & , \\
\hline 4 & Livestock & 3.41 & 0.64 & 3.55 & 0.72 & 3.48 & 0.68 & 0.56 & , & , \\
\hline 5 & Soil & 3.44 & 0.67 & 3.54 & 0.65 & 3.49 & 0.66 & 0.72 & , & , \\
\hline $\begin{array}{l}\mathrm{D} \\
1\end{array}$ & $\begin{array}{l}\text { Mitigation/Adaptation strategies } \\
\text { Use of wind, hydro and solar sources of energy }\end{array}$ & 3.52 & 0.71 & 3.76 & 0.90 & 3.64 & 0.85 & 0.40 & , & , \\
\hline 2 & Burying of wastes & 3.39 & 0.97 & 3.47 & 0.87 & 3.43 & 0.92 & 1.87 & , & , \\
\hline 3 & Encouraging green economy/afforestation & 3.59 & 0.52 & 3.50 & 0.91 & 3.55 & 0.71 & 0.94 & , & , \\
\hline 4 & Bio-engineering of microbes to eliminate GHG & 2.87 & 0.09 & 3.39 & 0.15 & 3.13 & 0.12 & 0.41 & , & ” \\
\hline 5 & $\begin{array}{l}\text { Filling the sky with Sulphur IV Oxide to block } \\
\text { intense solar rays }\end{array}$ & 3.56 & 0.21 & 3.39 & 0.90 & 3.33 & 0.55 & 1.28 & " & " \\
\hline 6 & Stipulating laws and policies & 3.82 & 0.98 & 3.66 & 0.83 & 3.74 & 0.91 & 0.93 & , & , \\
\hline
\end{tabular}

$\mathrm{Ho}_{1}$ : There is no significant difference in the mean rating of Lecturers and Extension agents on the content areas of climate change required for integration into the senior secondary school agricultural science curriculum.

Data for answering research question one and testing hypothesis one were presented in Table 1.

Data in Table 1 revealed that all the 23 items in the four clusters (A-D) had their grand mean $\left(\bar{X}_{\mathrm{G}}\right)$ values ranged from 3.13 to 3.94 ; the values were above 1.50 indicating that the entire four clusters and their corresponding items were required for integration into the secondary school agricultural science curriculum. The table also showed that the standard deviation $\left(\mathrm{SD}_{\mathrm{G}}\right)$ of the 23 items in the four clusters ranged from 0.10 to 0.92 ; indicating that the respondents were close to the mean and to one another in their responses. The table further revealed that the items in the four clusters had their t-calculated values lower that than the t-critical value at ( $\mathrm{p}$ 0.05 ) and 240 degrees of freedom. This showed that there is no significant difference in the mean ratings of lecturers and extension agents on the areas of climate change required for integration into the agricultural science curriculum, therefore the null hypothesis of no significant difference was accepted for each item. 
Table 2. Mean ratings of the respondents on the materials required for delivering the content areas of climate change in Secondary schools. $\mathrm{N}=242$ (55 Lecturers \& 187 Extension agents).

\begin{tabular}{|c|c|c|c|c|c|c|c|c|c|c|}
\hline $\mathbf{S} / \mathbf{N}$ & Item Statement on materials required & $\bar{X}_{\mathrm{L}}$ & $\mathbf{S D}_{\mathbf{L}}$ & $\bar{X}_{\mathrm{E}}$ & $\mathbf{S D}_{\mathrm{E}}$ & $\bar{x}_{\mathrm{G}}$ & $\mathrm{SD}_{\mathrm{G}}$ & t-cal & \multicolumn{2}{|c|}{ Remark } \\
\hline 1 & Anemometer for measuring wind speed & 3.69 & 0.22 & 3.93 & 0.45 & 3.81 & 0.64 & 0.57 & Required & NS \\
\hline 2 & Barometer for measuring pressure & 3.38 & 0.30 & 3.67 & 0.34 & 3.34 & 0.32 & 0.62 & , & , \\
\hline 3 & Computer device for forecasting weather & 3.56 & 0.82 & 3.71 & 1.01 & 3.64 & 0.95 & 1.45 & , & , \\
\hline 4 & Computer software for analyzing data & 3.72 & 0.29 & 3.98 & 0.11 & 3.85 & 0.20 & 0.76 & , & , \\
\hline 5 & Hygrometer for measuring relative humidity & 3.61 & 0.29 & 3.66 & 0.48 & 3.64 & 0.39 & 0.85 & , & , \\
\hline 6 & Thermometer for measuring temperature & 3.78 & 0.28 & 3.81 & 0.23 & 3.80 & 0.26 & 0.77 & , & , \\
\hline 7 & Rain gauge for measuring rainfall & 3.48 & 0.24 & 3.51 & 0.36 & 3.50 & 0.30 & 0.12 & , & , \\
\hline 8 & Wind vane for measuring wind direction & 3.21 & 0.22 & 3.33 & 0.28 & 3.27 & 0.25 & 0.31 & , & , \\
\hline 9 & Flow-meter for measuring gas flaring & 3.42 & 0.81 & 3.17 & 0.83 & 3.30 & 0.82 & 0.33 & , & , \\
\hline 10 & Demonstration farm & 3.45 & 0.92 & 3.72 & 0.84 & 3.59 & 0.88 & 0.11 & , & , \\
\hline 11 & Containers for the instructional material & 2.98 & 0.23 & 3.51 & 0.72 & 3.25 & 0.48 & 0.21 & ,, & ,, \\
\hline
\end{tabular}

\subsection{Research Question 2}

What are the materials required for effective teaching of the themes and topics on climate change in the senior secondary school agricultural science curriculum?

$\mathrm{Ho}_{2}$ : There is no significant difference in the mean rating of Lecturers and Extension agents on the materials required for effective teaching of the themes and topics on climate change in the senior secondary school agricultural science curriculum?

Data for answering research question two and testing hypothesis two were presented in Table 2.

Data in Table 2 revealed that all the 11 items had their grand mean $\left(\bar{x}_{\mathrm{G}}\right)$ values ranged from 3.25 to 3.85. The values were above 1.50 indicating that all the 11 items were materials required for teaching the themes and topics of climate change in secondary school. The table also showed that the standard deviation $\left(\mathrm{SD}_{\mathrm{G}}\right)$ of the11 items ranged from 0.25 to 0.88 ; indicating that the respondents were closed to the mean and to one another in their responses. The table further revealed that the 11 items had their t-calculated values lower that than the $t$-critical value at $(p>0.05)$ and 240 degrees of freedom. This showed that there is no significant difference in the mean ratings of lecturers and extension agents on the materials required for teaching the themes in climate change in secondary school, therefore the null hypothesis of no significant difference was accepted for each of the items.

\section{Discussion of the Result}

The result of the study in Table 1 revealed that the areas of climate change required for integration into the senior secondary school agricultural science curriculum were concepts, causes, and effect of climate change in addition to mitigation/adaptation strategies. The findings of the study were in line with the findings of [16] in a study on integrating climate change issues into agricultural education teaching and learning in Nigeria in which it was found out that the curriculum content on climate change could be based on agro-bio-diversity, biofuels, mitigation strategies and global policy issues. The findings of the study were also in consonance with the findings of [5] that the areas of climate change that could be integrated into the curriculum are introduction to climate change, global warming, agro-biodiversity, bio-fuels, adaptation strategies, mitigation strategies and global policy issues among others.

The result of the study in Table 2 revealed that the materials required for teaching the integrated areas of climate change were anemometer, Barometer, computer devices and software, wind vane, flow-meter, rain-gauge and container among others. The findings of the study were in agreement with the findings of [17] in a study on infusion of climate change into teacher preparation in agriculture in primary education studies in colleges of 
education where it was found out that thermometer, hygrometer, wind vane among others were materials needed for delivering the content areas of climate change.

The findings of the authors helped to validate the findings of this study on integration of climate change into the senior secondary school agricultural science curriculum.

\section{Conclusion}

It is the wish of every individual in the society to make necessary contribution to help overcome the impact of climate change. The students of agricultural science in the area of the study need to be acquainted with the concept of climate change, causes, effects and mitigation/adaptation strategies. The teaching could help in disseminating the learned information to other members of the society but this could only be achieved if climate change is integrated into the senior secondary schools agricultural science curriculum. This study has therefore identified the areas of climate change required for integration into the curriculum and the materials required for effective teaching of the content identified.

\section{Recommendations}

Based on the findings of the study, it was recommended that:

1) The identified content areas be integrated into the curriculum of secondary schools in countries with secondary education, such as Nigeria by the Nigerian Educational Research and Development Council (NERDC) to keep the students abreast with the challenges and mitigation strategies of climate change.

2) Federal Ministry of Education should organize workshop for the teachers of agricultural science in secondary school (in Nigeria) to up-skill their knowledge on climate change and its variables and make them competent in teaching their students.

\section{References}

[1] Intergovernmental Panel on Climate Change (2001) Glossary-Climate Change Education Center-Arctic Climatology and Meteorology. NSIDC National Snow and Ice Data Center. http://www.grida.no/climate/ipcc tar/wg1/518.htm

[2] Uyigue, E. and Agho, M. (2007) Coping with Climate Change and Environmental Degradation in the Niger Delta of Southern Nigeria. Community Research and Development Centre (CREDC) Press, Benin.

[3] Intergovernmental Panel on Climate Change (2007) Impacts, Adaptation and Vulnerability. Summary for Policymakers, in Climate Change: Contribution of Working Group II to the Fourth Assessment Report of the Intergovernmental Panel on Climate Change. Cambridge University Press, Cambridge.

http://www.ipcc.ch/pdf/assessment-report/ar4/syr/ar4_syr_spm.pdf

[4] Naomi, O. (2004) The Scientific Consensus on Climate Change. Science, 306, 1686.

[5] Chikaire, J., Nnadi, F.N., Orusha, J.O. and Onogu, B. (2012) Integrating Climate Change Issues into Agricultural Education Teaching and Learning in Nigeria. Advances in Agriculture, Sciences and Engineering Research Journal, 2, 115-127.

[6] Brubacher, J.S. (1961) Modern Philosophies of Education. McGraw-Hill Book Company, New York.

[7] Chakeredza, S., Temu, A.B., Yaye, A., Mukingwa, S. and Saka, J.D. (2009) Mainstreaming Climate Change into Agricultural Education: Challenges and Perspectives. ICRAF Working Paper No. 82, World Agroforestry Centre, Nairobi.

[8] Offorma, G.C. (2002) Curriculum Theory and Planning. Family Circle Publications, Uwani Enugu, Nigeria.

[9] International Labour Organization (1999) Safety and Health in Agriculture. Geneva.

[10] Talathi, J.M., Naik, G.V. and Jalgaonkar, V.N. (2011) Introduction to Agricultural Economics and Agribusiness Management. Ana Book Publishers, New Delhi.

[11] Padgham, J.,Virji, H. and Seipt, C. (2013) Promoting Climate Change Curricula Development in African Universities. Environmental Development, 5, 169-171. http://dx.doi.org/10.1016/j.envdev.2012.08.001

[12] Selim, I. (2012) Climate Change and Environmental Education. UNICEF Division of Communication, New York.

[13] Hart, R. (1996) Children's Participation in Sustainable Development: The Theory and Practice of Involving Young Citizens in Community Development and Environmental Care. Earthscan, London.

[14] Institute for the Promotion of Teaching Science and Technology (2011) Climate Change Integrated Education Model: Building Adaptive Capacity for the Next Generation (Malaysia, Indonesia, Thailand, Philippines and Lao PDR). Project Reference No. CBA2011-09NSY-Aligaen SEAMEO RECSAM-APN. 
[15] Henry, O.O., Emmanuel, G.K. and Amponsah, M.O. (2012) Assessment of Junior High School Students’ Awareness of Climate Change and Sustainable Development in Central Region, Ghana. Educational Research Journal, 2, 308-317.

[16] Orusha, J.O., Alukogu, C.T., Nwigwe, M.O., Ohuaka, P. and Tim-Ashamu, A. (2012) Integrating Climate Change Issues into Agricultural Education and Learning in Nigeria. Global Advance Research Journal of Educational Research and Review, 1, 57-67.

[17] Alaribe, M.O., Okirie, L.B. and Olaitan, S.O. (2013) Infusion of Climate Change into Teacher Preparation in Agriculture in Primary Education Studies in Colleges of Education. Presented at Annual Conference of Curriculum Organization of Nigeria (CON), Port-Harcourt River State. 
Scientific Research Publishing (SCIRP) is one of the largest Open Access journal publishers. It is currently publishing more than 200 open access, online, peer-reviewed journals covering a wide range of academic disciplines. SCIRP serves the worldwide academic communities and contributes to the progress and application of science with its publication.

Other selected journals from SCIRP are listed as below. Submit your manuscript to us via either submit@scirp.org or Online Submission Portal.
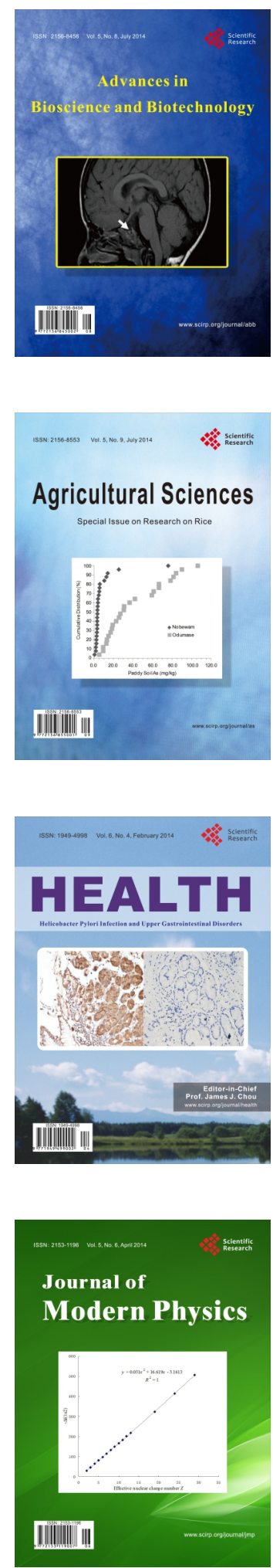
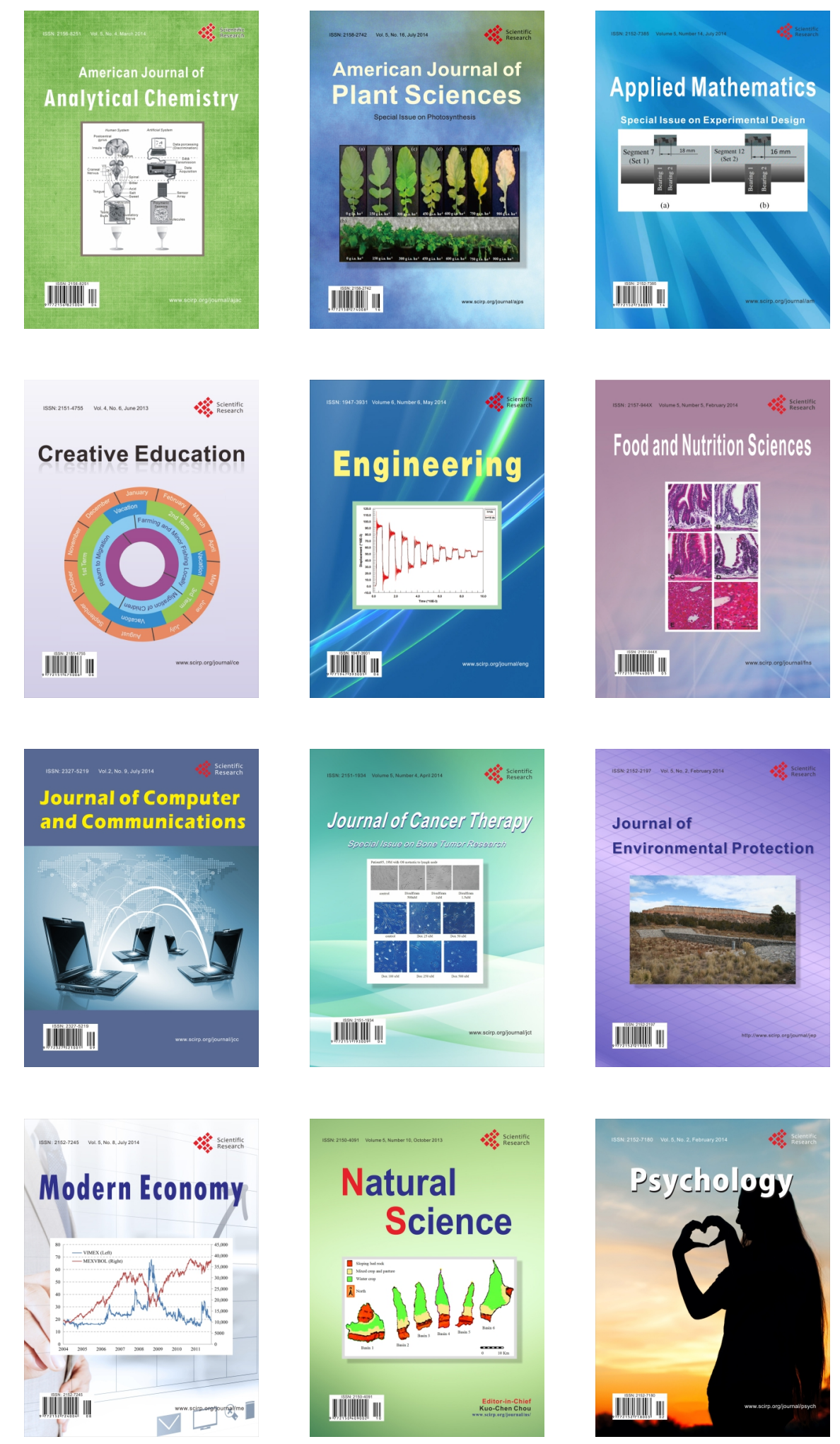